\title{
STRATEGI KOMUNIKASI INOVASI DALAM PERUBAHAN SISTEM PERTANIAN JAGUNG HIBRIDA MADURA-3 DI KABUPATEN PAMEKASAN
}

\author{
Imam Sofyan \\ Prodi Ilmu Komunikasi, Fakultas Ilmu Sosial dan Ilmu Budaya, \\ Universitas Trunojoyo Madura \\ Email: imamsofyan@hotmail.com.
}

\begin{abstract}
Corn farming remains a culture besides a necessity for the Madurese community, not only as a provider of typical food sources, but also as a support for the economy of the local community. This encourages the need for an counceling communication approach to reassure farmers to exchange from the ordinary corn agricultural system to Madura-3 hybrid corn to increase productivity. This study aims to describe the communication strategy in the dissemination of M3 hybrid corn innovations to Madurese farmers. The research setting took local corn farmers in the Pasean Pamekasan sub-district. With the descriptive method, the data was obtained through interviews and semi-participatory observation to farmer groups. The results of the study illustrate that the communication process of innovation is carried out through four stages, namely socialization, the role of poktan, demoplot, and mentoring. The messages flows through the context of interpersonal communication channels, groups, opinion leaders, and worth of mouth communication. Furthermore, the pattern of innovation acceptance by farmers occurs through assistance, technical assistance and utilization of farm houses.
\end{abstract}

Keywords: Communication strategy, communication innovation, opinion leaders, the changes of agricultural systems

\section{ABSTRAK}

Bertani jagung menjadi budaya sekaligus kebutuhan bagi masyarakat Madura, tidak saja sebagai penyedia sumber makanan khas, melainkan juga penopang perekonomian masyarakat lokal. Hal tersebut, mendorong perlunya pendekatan komunikasi penyuluhan untuk mengajak masyarakat petani berpindah dari sistem pertanian jagung biasa ke jagung hibrida Madura-3 guna peningkatan produktifitas. Penelitian ini bertujuan untuk memaparkan strategi komunikasi dalam penyebaran inovasi jagung hibrida M3 pada petani Madura. Setting penelitian mengambil petani jagung lokal di wilayah kecamatan Pasean Pamekasan. Dengan metode deskriptif, data digali melalui wawancara dan observasi semi partisipatoris terhadap kelompok-kelompok tani. Hasil penelitian menggambarkan bahwa proses komunikasi inovasi dilakukan melalui empat tahapan, yakni sosialisasi, peran poktan, demoplot, dan pendampingan. Penerusan pesan berjalan melalui konteks saluran komunikasi interpersonal, kelompok, opinion leader, gethok tular. Selanjutnya pola penerimaan inovasi oleh petani berlangsung lewat pendampingan, bimtek dan pemanfaatan rumah pertanian.

Kata kunci: Strategi komunikasi, komunikasi inovasi, pemimpin opini, perubahan sistem pertanian 


\section{PENDAHULUAN}

Mengkomunikasikan suatu pesan inovasi ke dalam lingkungan masyarakat pedesaan, seperti halnya kepada para petani, dibutuhkan suatu pendekatan khusus dengan memahami karakteristik sistem sosial budaya mereka. Pendekatan komunikatif perlu dirancang, tidak saja dalam hal cara penyampaian ide gagasan, namun juga penggunaan saluran-saluran komunikasi tradisional yang dapat menggugah ketertarikan masyarakat untuk berpartisipasi aktif dalam tindakan komunikasi. Hal ini diperlukan, agar komunikasi partisipatif dapat terjalin, sehingga pesan tidak cukup untuk dimengerti baik, tetapi juga dibutuhkan oleh masyarakat. Sebagaimana tujuan komunikasi bermaksud untuk merubah perilaku orang lain, maka pembentukan information seeking perlu diupayakan tertanam pada diri tiap individu.

Hubeis (2007) menyatakan bahwa inovasi merupakan gagasan, tindakan atau barang yang dianggap baru bagi seseorang atau kelompok masyarakat tertentu. Meski demikian, suatu inovasi dapat juga berisikan informasi atau temuan lama, namun dalam penerapannya relatif baru, yakni belum pernah dicoba sebelumnya pada kalangan masyarakat tertentu. Oleh sebab itu, kebaruan suatu inovasi akan sangat bergantung pada perspektif individu penerima pesan. Komunikasi Inovasi adalah proses interaksi sosial melalui pesan inovasi baik berupa gagasan, tindakan ataupun obyek tertentu kepada orang lain guna pembaharuan kebiasaan lama. Komunikasi inovasi secara umum dilakukan dalam bentuk komunikasi penyuluhan. Tujuan dari metode komunikasi ini adalah untuk memobilisasi prilaku suatu kelompok masyarakat guna mengadopsi sesuatu hal baru dalam sistem kehidupannya.

Masyarakat Madura merupakan masyarakat yang bercorak tradisional. Selain bekerja sebagai nelayan, sebagian besar penduduknya menggantungkan hidup pada mata pencaharian pertanian, mulai dari bertanam jagung, garam, padi, hingga tembakau. Dari beberapa cocok tanam tersebut, pertanian jagung merupakan komoditas utama penunjang perekonomian masyarakatnya, yang sebagian besar banyak diproduksi di kabupaten Pamekasan.

Berdasarkan data statistik daerah, lahan pertanian di Kabupaten Pamekasan seluas 64.919 Ha atau $81.94 \%$ dari total luas wilayah. Sedangkan sisanya yaitu $18.06 \%$ berupa lahan bukan pertanian. Wilayah seluas $26.84 \%$ berupa lahan sawah, yang terdiri dari sawah tadah hujan 11.284 Ha, dan lahan sawah teknis seluas 7.500 Ha. Sebagian besar lainnya, yakni $73.55 \%$ areal pertanian di wilayah ini berupa tegalan, ladang, perkebunan, hutan rakyat dan kolam/tebat/empang.

Ditinjau dari mata pencaharian masyarakat, terdapat $45 \%$ penduduk berprofesi sebagai petani, yang sebagian besar bertani jagung dengan luas tanaman jagung adalah $6.038 \mathrm{Ha}$, dan total luas kemampuan panen berkisar 8.725 Ha. Data tersebut menunjukkan bahwa sektor pertanian jagung di Pamekasan sangat potensial untuk dikembangkan dan dikelola secara lebih baik. Terlebih apabila mengadopsi model sistem pertanian baru, yakni sistem pertanian hibrida yang dinilai jauh lebih unggul dari pada pertanian biasa.

Meski demikian, produktivitas jagung di masyarakat Pamekasan ini masih terbilang rendah karena disebabkan oleh lahan yang 
kurang subur, curah hujan yang minim, serta petani jagung umumnya masih menggunakan benih jagung lokal yang diambil dari hasil produksi sendiri. Lebih dari $90 \%$ hasil produksi yang dikembangkan untuk pangan merupakan jagung lokal. Keadaan ini seharusnya menjadi alasan kuat bagi para petani untuk memilih sistem bercocok tanam jagung ke yang lebih produktif, seperti menggunakan jagung varietas hibrida Madura yang dikembangkan Universitas Trunojoyo Madura.

Jagung varietas hibrida Madura 3 (M3) merupakan produk inovasi, yakni benih jagung pengembangan-persilangan jagung Meksiko dengan tetua jagung Madura. Inovasi jagung ini adalah hasil riset dari peneliti Program Studi Agro Teknologi Fakultas Pertanian Universitas Trunjoyo Madura. Jagung inimemiliki kelebihan yakni mampu berproduksi hingga tiga kali lipat mencapai 7.9 ton per hektare dibanding jagung biasa yang hanya mencapai umumnya 2.5 ton per hektare. Selain itu, benih ini memiliki kandungan beta karoten tinggi sehingga sangat sesuai untuk digunakan sebagai bahan pangan dan pakan. Lebih jauh jagung varietas hibrida ini diharapkan dapat menjadi penopang untuk kepentingan kebutuhan jagung nasional.

Atas dasar itu, inovasi benih jagung yang telah mendapatkan sertifikasi dari Balitsereal Balitbang Kementerian Pertanian sebagai jagung varietas hibrida unggulan ini, dinilai dapat menjadi solusi dalam upaya meningkatkan perekonomian masyarakat Madura melalui perubahan sistem pertanian jagung lokal ke jagung hibrida. Meski memiliki keunggulan dan nilai manfaat yang besar, keberadaan jagung hibrida M3 ini belum diterima secara massal oleh masyarakat
Madura, termasuk kebanyakan petani di daerah Pamekasan. Beberapa permasalahan yang muncul diantaranya; kurangnya pemahaman masyarakat tentang keunggulan jagung varietas hibrida, minimnya sosialisasi dan pelatihan bagi petani, serta kurang tersedianya informasi seputar sistem pertanian jagung varietas hibrida M3 di kantong-kantong pedesaan. Informasi tersebut meliputi metode bercocok tanam, pengolahan, pembenihan, periodisasi panen, sampai pada paska produksi hasil panen.

Untuk mengurai akar persoalan tersebut, diperlukan strategi komunikasi yang dapat mengubah perilaku petani. Beberapa hal yang perlu diperhatikan pada menurut Kusumadinata dan Fitrah (2017), diantaranya kekuatan sang komunikator, penyederhanaan pesan, memahami karakater khalayak sasaran, dan pemanfaatan saluran media yang sesuai kultur, serta peninjauan dampaknya terhadap masyarakat agar dapat diterima. Berdasarkan pada permasalahan tersebut, maka dilakukan penelitian strategi komunikasi inovasi dalam perubahan petani jagung konvensional ke jagung varietas hibrida Madura-3 di kecamatan Pasean kabupaten Pamekasan.

Beberapa studi terkait komunikasi penyuluhan ataupun komunikasi pembangunan pada kelompok tani memperlihatkan pergeseran metode pendistribusian pesan. Menurut Sadono (2009) pola komunikasi dalam penyuluhan pertaniandiIndonesiamengalamiperkembangan dari waktu ke waktu. Pada mulanya komunikasi yang dikembangkan berupa pola komunikasi yang bersifat linear dari pemerintah/peneliti melalui penyuluh kepada petani. Namun sejalan dengan perkembangan pemahaman pemerintah atau peneliti, serta kemajuan yang dialami 
oleh petani, tuntutan kemandirian pada bidang pertanian, maka pola komunikasi penyuluhan pertanian juga mengalami perubahan berupa komunikasi partisipatif dan dialogis.

Kajian penelitian yang dilakukan oleh Rangkuti (2009) menunjukkan bahwa kemandirian pangan bergantung pada keberdayaan petani dalam meningkatkan produktivitas, kualitas produk, dan nilai tambah sehingga mempunyai posisitawar dan daya saing yang tinggi. Sementara untuk mewujudkannya diperlukan dukungan akselerasi adopsi inovasi sistem teknologi pertanian. Sementara Budhirianto (2015) melakukan kajian tentang pola komunikasi pemberdayaan kelompok informasi masyarakat dalam penyukseskan swasembada pangan. Hasil penelitian ini menyimpulkan tentang pola atau model komunikasi sistem pendampingan yang lebih terarah dari seluruh stakeholder, serta bisa juga dikembangkan melalui komunikasi kelompok, selain itu juga diperlukan komunikasi linier baik secara top down ataupun bottom up dengan para stakeholder.

Kajian lain yang dilakukan oleh Sugiarti dan Hayati (2009) terkait persepsi petani madura dalam menolak komoditas jagung varietas baru dengan metode survei dan wawancara terstruktur mendalam. Hasil penelitian ini, menunjukkan bahwa keputusan petani untuk menanam jagung tersebut didasarkan kepada kebutuhan pangan, varietas lokal masih lebih disukai, serta kendala berusaha tani jagung masih besar, terutama pada aspek terkait permodalan, sarana dan prasarana, pemasaran, juga pengetahuan yang rendah.

Selanjutya penelitian Sapari dkk. (2009) dengan tentang pemanfaatan media komunikasi prima tani, aksesibilitas kelembagaan tani, dan persepsi petani terhadap teknologi agribisnis industrial pedesaan. Penelitian ini menggunakan metode survei deskriptif korelasional. Populasi penelitian adalah 1.298 orang petani yang tersebar di Kabupaten Garut dan Karawang Jawa Barat serta di Kabupaten Pangkep dan Luwu, Sulawesi Selatan. Hasil penelitian ini salah satunya adalah bahwa gelar teknologi, media komunikasi dan klinik agribisnis berhubungan nyata dengan persepsi petani kooperator di Jawa Barat dan Sulawesi Selatan tentang teknologi AIP pada aspek biofisik, sosial dan ekonomi.

Kajian berikutnya dilakukan oleh Pertiwi dan Saleh (2010) yakni persepsi petani tentang saluran komunikasi usaha tani padi. Penelitian ini menggunakan metode survei kuesioner dan wawancara mendalam. Hasil penelitian ini menguraikan pandangan yang baik dari petani terhadap saluran komunikasi penyuluhan perlu dibentuk dan terus dipupuk. Tujuannya adalah agar petani mampu dan berminat mengakses berbagai saluran dalam mencari atau mempelajari inovasi-inovasi pertanian yang sedang merebak di lingkungannya.

Lebih lanjut, Firmansyah dkk (2017) melakukan penelitian tentang strategi komunikasi dalam penguatan kapasitas kelembagaan pada pengelolaan lahan gambut di sektor pertanian. Penelitian ini menguraikan strategi komunikasi dilakukan untuk memperkuat kapasitas kelembagaan melalui peningkatan dukungan penyuluh pertanian sebagai komunikator, peningkaatan kedinamisan kelompok tani sebagai kelompok belajar dan penyebaran informasi pertanian 
(pesan inovasi), penganekaragaman sumbersumber informasi dan teknologi pertanian (saluran, media) dan peningkatan kapasitas petani dalam kegiatan penyuluhan (komunikan).

Dari beberapa kajian terdahulu nampak pentingnya strategi komunikasi dalam mengurai masalah-masalah pertanian di masyarakat. Penelitian ini bertujuan untuk memaparkan tiga persoalan, diantaranya; (1) bagaimana proses komunikasi inovasi pertanian tersebut dilakukan pada petani lokal Pasean. (2) bagaimana penggunaan saluran komunikasi sosial tradisional dimanfaatkan untuk menruskan pesan inovasi. (3) bagaimana pola penerimaan petani terhadap pesan inovasi tersebut.

Orientasi utama skema penelitian ini adalah pada pengembangan teoritik kajian komunikasi penyuluhan khususnya terkait komunikasi pembangunan pertanian. Dengan target khusus diperoleh deskripsi pengetahuan strategi komunikasi dalam penyebarluasan pesan inovasi Jagung Hibrida Madura 3 yang dikenal dengan sebutan M3 tersebut pada petani lokal Madura. Dengan demikian dapat memberi kontribusi pada praktik penyuluhan pertanian baik yang dilakukan oleh institusi universitas maupun para pendamping pertanian guna mendukung program-program pemerintah dalam meningkatkan kesejahteraan petani tradisional melalui pengembangan sistem pertanian baru.

\section{METODE PENELITIAN}

Penelitian ini menggunakan metode kualitatif sebagai upaya mengungkapkan penejelasan secara lebih mendalam tentang suatu fenomena sosial. Metode kualitatif menekankan pada realitas yang dibentuk melalui proses sosial, serta hubungan yang dekat antara peneliti dengan objek yang diteliti. (Richad, 2009).

Penelitian ini bertujuan untuk mengumpulkan informasi terbaru secara lebih terperinci dengan menggambarkan gejalagejala sosial tetang penerimaan masyarakat terhadap program baru pertanian. Selain itu, penggunaan metode ini untuk mengidentifikasi dan menguraikan fakta-fakta dilapangan seputar persoalan strategi komunikasi dalam perubahan petani, meliputi pengetahuan, sikap dan tindakan masyarakat.

Penelitian dilakukan selama 3 bulan (September-Desember2018)dengan mengambil sampel 3 desa dikecamatan Pasean kabupaten Pamekasan. Metode penggalian data dilakukan melalui wawancara mendalam terhadap kepala desa, ketua kelompok tani (poktan), petani jagung dan pendamping pertanian. Sedangkan observasi semi partisipatoris dipilih untuk bisa terlibat dalam aktifitas keseharian pengelolaan pertanian masyarakat lokal.

\section{HASIL DAN PEMBAHASAN \\ Proses penerapan hibrida UTM 3 di Kecamatan Pasean}

Pola komunikasi dalam penyuluhan pertaniandiIndonesiamengalamiperkembangan dari waktu ke waktu. Pada mulanya komunikasi yang dikembangkan berupa pola komunikasi yang bersifat linear dari pemerintah/peneliti melalui penyuluh kepada petani. Namun sejalan dengan perkembangan pemahaman pemerintah atau peneliti, kemajuan yang dialami oleh 
petani, tuntutan demokrasi pada bidang pertanian, maka pola komunikasi penyuluhan pertanian juga mengalami perubahan berupa komunikasi partisipatif dan dialogis.

Strategi perubahan pertanian dari konvensional ke jagung varietas hibrida sedikitnya melalui empat proses strategi yang bertama berupa sosialisasi langsung kepada masayrakat. Dalam upaya mewjudkan perubahan bertani dari jagung konvensional ke jagung hibrida UTM3 perlu dilakukan sosialisasi secara berkesinambungan guna memberikan pemahaman yang lengkap tentang sistem pertanian jagung hibrida. Sosialisasi dilakukan bertujuan memberikan pemahaman yang utuh dan terperinci atas seluruh prosesnya. Secara umum pertanian jagung di Madura berbicara pada lima proses utama berupa pengolahan dan pembajakan sawah, penanaman, perawatan, panin dan pasca panin.

Pada proses perubahan pertanian jagung konvensional ke hibrida UTM 3 Kedua diperlukan peran kelompok tani baik yang dibentuk oleh pemerintah ataupun oleh lembagalembaga swasta. Keberadaan kelompok tani dapat memperlancar arus informasi sistem pertanian dengan teknologi baru untuk dapat di adopsi oleh masyarakat melalui pendampingan dan pengawasan.

Nurhayati dan Swastika (2011) mengatakan pemerintah dan pihak swasta dapat bekerjasama dengan anggota petani dengan menjalin kemitraan. Artinya kerjasama dalam bentuk apa pun diharapkan dapat mengungkit peran serta aktif kelompok untuk meningkatkan taraf ekonomi atau kesejahteraan kelompok karena kelompok tani merupakan pelaku perubahan, termasuk teknologi. Pada pertanian jagung varietas hibrida UTM 3, kelompok tani dapat berperan sebagai pendamping pertanian seluruh proses pertanian seperti misalnya, pengaturan waktu tanam, jarak tanam, pengolahan lahan dan pengairan, dan sebagainya akan lebih efektif apabila dilakukan pengawasan secara intens oleh kelompok tani.

Menurut Pak Farid yang diwawancarai pada 17 Oktober 2018 di desa ini progam pertanian desa semua berjalan lancar terutama kelompok taninya. Disini kelompok tani aktif mulai dari program pendampingan pertanian, sosialisasi pertanian sampai pada urusan pupuk pertanian. Kegiatan pertanian di desa ini banyak melalui kelompok tani.

Kelompok tani memiliki peranan yang sangat menentukan dalam proses pertanian masyarakat di Kabupaten Pamekasan. Kelompok tani memiliki peranan penting dalam melakukan sosialisasi pertanian. Kelompok tani yang berada di tingkatan dusun memiliki peranan pendampingan pertanian seperti sosialisasi sampai pada persoalan pupuk pertanian. Selain itu keberadaan POKTAN atau kelompok tani dipandang sebagai lembaga yang tepat dalam melalukan program perubahan pertanian jagung konvensional ke jagung varietas hibrida UTM 3.

Ketiga melalui Demoplot. Model demplot atau percontohan merupakan salah satu strategi yang bisa dilakukan dalam upaya mewujudkan perubahan pertanian dari pertanian konvensional ke jagung hibrida UTM 3. Praktek dempoplot atau demplot bisa dilakukan di tingkat desa di seluruh Kecamatan Pasean sehingga demplot ini dapat menjadi model percontohan bagi 
masyarakat. Sebagaimana penuturan salah satu informasi kami berikut ini:

Menurut Saprawi yang diwawancarai pada 2 Oktober 2018 agar supaya masyarakat Kecamatan Pasean merubah model pertaniannya dari konvensional ke pertanian hibrida langkah pertama perlu dilakukan melalui percontoan atau demoplot. Percontohan ini bisa dilakukan di desa dengan model bekerjasama dengan pihak desa sehingga desa dapat memfasilitasi lahannya. Hasil dari percontohan ini apabila berhasil dapat memotifasi masyarakat untuk melakukan penanaman jagung hibrida.

Yang keempat berupa Pendamping pertanian yang memiliki peran besar dalam menentukan keberhasilan program inovasi pertanian. Adanya interaksi yang intens antara petani dengan pendamping pertanian dapat melahirkan saling percaya, saling bergantung dan saling membutuhkan untuk mewujudkan pertani yang mandiri.

Menurut Jafri dkk. (2015) suatu interaksi sosial yang dapat mengakselerasi dinamika faktor-faktor imitasi, sugesti, identifikasi, dan simpati antara kedua belah pihak yang berinteraksi akan sangat bermanfaat untuk memunculkan rasa saling ketergantungan, saling pengertian, yang akhirnya akan menjadi kekuatan untuk mendorong kemandirian pada pihak kelompok tani sasaran. Sementara kegagalan memaknai hal tersebut hanya dapat memperlambat terwujudnya perubahan perilaku sebagai upaya mendorong kemandirian.

Jagung varietas hibrida UTM 3 ini bisa berhasil dilakukan dan bisa diadopsi oleh masyarakat Kecamatan Pasean kalau seluruh poses penanamannya dilakukan pendampingan supaya masyarakat tau cara menanam yang benar sehingga hasilnya sesuai dengan apa yang menjadi harapan pihak kampus. Proses penerapan hibrida UTM 3 di Kecamatan Pasean dapat digambar sebagaimana berikut ini:

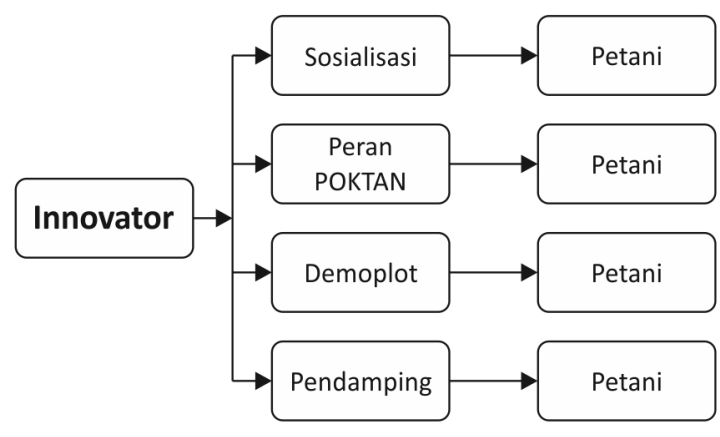

\section{Gambar 1. \\ Proses penerapan hibrida UTM 3}

Proses penerapan hibrida UTM 3 diperlukan adanya inisiatif dari innovator atau kelompok masyarakat memiliki kepedulian terhadap peningkatan produksi jagung di Kecamatan Pasean. Proses penerapan ini dilakukan melalui sosialisasi langsung kepada masyarakat. Kedua melalui optimalisasi peran kelompok tani sesuai dengan tugasnya untuk melakukan pendampingan pertanian di tingkat desa. Berikutnya perlunya demplot sebagai sarana percobaan penanaman jagung hibrida, terakhir bahwa seluruh proses tersebut diperlukan pendamping pertanian yang secara intens dapat mengontrol seluruh proses penanaman jagung hibrida UTM 3.

\section{Model strategi perubahan petani jagung konvensional ke jagung hibrida UTM 3}

Menurut Effendy, (2005) ada empat tujuan dalam strategi komunikasi sebagai berikut: pertama to secure understanding 
yaitu untuk memastikan bahwa terjadi suatu pengertian dalam berkomunikasi. Kedua to establish acceptance, yaitu bagaimana cara penerimaan itu terus dibina dengan baik. keempat to motivate action yaitu penggiatan untuk memotivasinya, dan yang terakhir to goals which communicator sought to achieve yaitu bagaimana mencapai tujuan yang hendak dicapai oleh pihak komunikator dari proses komunikasi tersebut.

Jagung varietas hibrida UTM 3 sejatinya merupakan pertanian modern dengan peningkatan kapasitas, kualitas, dan produktivitas hasil pertanian. Jagung varietas hibrida UTM 3 merupakan manifetasi dari aplikasi kemajuan teknologi yang berkembang dalam setiap langkah kehidupan suatu masyarakat. Modernisasi pertanian meliputi beberapa elemen penting yang harus diperhatikan diantaranya tersedianya bahanbahan dan alat produksi, tersfasilitasinya teknologi baru, tersedinya informasi pertanian, serta adanya rangsangan produksi bagi petani
Berdasarkan alasan tersebut maka sosialisasi perubahan pertanian dari jagung konvesional ke jagung varietas hibrida perlu terus dilakukan dengan melibatkan semua elemen masyarakat terutama yang memiliki kepentingan dengan pengembangan perubahan dari konvensional ke jagung varietas hibrida UTM 3. Dalam wawancara yang dilakukan pada tanggal 3 Oktober 2018, Nom Saprawi mengatakan bahwa supaya

masyarakatMaduramerubahmodelpertaniannya dari konvensional ke pertanian hibrida langkah pertama perlu dilakukan melalui percontoan atau demoplot. Percontohan ini bisa dilakukan di desa dengan model bekerjasama dengan pihak desa sehingga desa dapat memfasilitasi lahannya. Hasil dari percontohan ini apabila berhasil dapat memotifasi masyarakat untuk melakukan penanaman jagung hibrida.

Sebagaimana terlihat pada gambar model berikut ini sebagai hasil penelitian proses peruahan petani jagung konvensional ke jagung hibrida UTM 3.

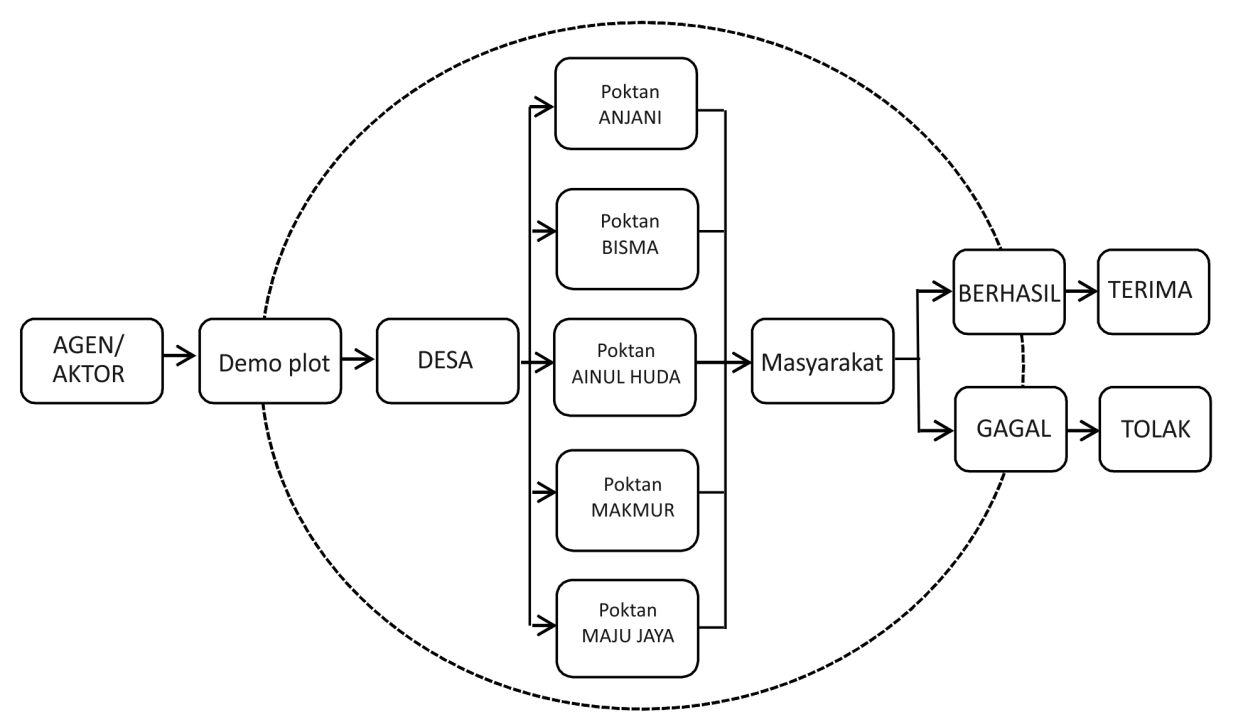

Gambar 2.

Proses perubahan petani jagung konvensional ke jagung hibrida UTM 
Pertama gambar diatas menunjukkan bahwa agen, aktor atau komunikator merupakan representasi dari akademisi, pendamping pertanian, dan lembaga yang memiliki program pengambangan jagung hibrida dalam hal ini adalah kampus Universitas Trunojoyo Madura. Akademis merupakan tokoh yang mengembangkan kajian dan berhasil menemukan pola pertanian jagung hibrida madura. Pendamping pertanian merupakan mahasiswa yang diperbantukan oleh lembaga untuk mengawasi seluruh proses pertanian, dan lembaga bertanggung jawab mengembangakn seluruh proses pertanian sesuai dengan klaster pengembangan universitas yang salah satunya adalah jagung hibrida UTM 3.

Demo plot atau demplot merupakan aktivitas penanaman yang dilakukan sebagai percontohan kepada masyarakat. Demplot berfungsi untuk mengenalkan kepada masyarakat tentang metode pertanian baru yang memiliki keunggulan mulai dari benihnya sampai pada sampai pada hasil paninnya. Keunggulan ini seharusnya menjadi daya tarik bagi masyarakat sekitar demplot untuk juga mempraktekkan metode pertanian jagung varietas hibrida ini.

Desa memiliki peranan yang cukup vital dalam menentukan keberhasilan program perubahan pertanian konvensional ke vairtas hibrida. Desa melalui kepala desa dan seluruh perangkat desa berperan untuk mendukung program ini. Bentuk dukungan desa melalui penyediaan sumber daya manusia, penyediaan lahan pertanian, fasilitas air yang mencukupi, sampai pada pembelian benih jagung hibrida. Bentuk partispasi ini memberikan peluang tercapainya tujuan kesejahteraan masyarakat Madura.

Poktan atau kelompok tani sebagaimana perannya pada tingkat dusun berupa pendampinngan pertanian kepada masyarakat. Kelompok tani memiliki akses yang sangat luas kepada masyarakat lebih daripada itu bahwa kelompok tani mengetahui secara detail tentang karakter petani desa. Melalui modal tersebut kelompok tani dapat menentukan polapola sosialisasi yang efektif dan menentukan kelompok masyarakat yang memiliki komitmen pengambangan jagung hibrida. Dalam wawancara dengan Nom Addur yang dilakukan pada tanggal 4 Oktober 2018, mengatakan kelompok tani juga aktif berkegiatan sehingga sosialisasi hibrida juga bisa dilakukan melalui kelompok tani.

Masyarakat sebagai target audiens menjadi perhatian utama dari seluruh rangkai perubahan pertanian. Masyarakat dengan segala karakter dan kebiasaanya membutuhkan pendekatan-pendekatan khusus untuk mengetahui sikapnya terhadap program baru bidang pertanian. Masyarakat melalui modal pengalaman bertani dari nenek moyang terdahulu cenderung sulit untuk merubah kebiasaan cara bercocok tanamnya. Oleh karena itu pendekatan kulutural untuk mengetahui sikap masyarakatnya.

Seluruh rangkaian perubahan petani jagung konvensional ke jagung hibrida UTM 3 berorientasi pada hasil. Hasil program pertanian hibrida menentukan bagaimana langkah diambil berdasarkan penilaian hasil akhir. Konsekwensi dari tindakan ini adalah apabila berhasil akan diterima dan akan menjadi 
model pertanian baru, namun apabila model percontohan gagal maka kecenderungan petani, kepala dan perangkat desa, serta kelompok tani akan menolaknya. Kenyetaan ini merupakan konsekwensi logis yang dapat diterima dan terjadi dalam kehidupan sosial masyarakat Pamekasan.

\section{KESIMPULAN}

Upaya perubahan pertanian dari jagung konvesional ke jagung varietas hibrida harus dilakukan dengan melibatkan semua elemen masyarakat terutama yang berhubungan langsung dan memiliki kepentingan dengan pengembangan perubahan dari konvensional ke jagung varietas hibrida UTM 3. Rumusan perubahan pertanian dari jagung konvesional ke jagung varietas hibrida perlu memperhatikan seluruh proses perubahan mulai dari agen atau aktor yang bertindak sebagai inisiator perubahan pertanian, metode percontohan penanaman hibrida di tingkat desa, pentingnya peranan kepala desa untuk memfasilitasi kegiatan penanaman jagung hibrida, proses sosialisasi melalui pemanfaatan kelompok tani pada tingkat dusun, serta masyarakat sebagai bagian terpenting untuk dapat berpatisipasi secara aktif mengukuti seluruh rangkaian proses pertaian jagung hibrida UTM 3.

Peranan strategi komunikasi dalam mengurai masalah-masalah pertanian sebagai perencanaan dan pengaturan untuk mencapai suatu tujuan yang telah ditetapkan dalam bidang pertanian. Dalam upaya untuk mencapai tujuan pada bidang pertanian tersebut strategi komunikasiberfungsi sebagaipetunjuk arah serta sebagai petunjuk taknik cara melakukannya.
Strategi komunikasi dapat dilakukan melalui konteks komunikasi kelompok, opinion leader, komunikasi antarpersonal, maupun model komunikasi gethok tular. Strategi komunikasi. Konteks komunikasi dapat memberikan efek yang berpengaruh pada aspek pengetahuan, sikap dan tindakan penerima pesan. Pengetahuan tentang pertanian yang terus bertambah, sikap terhadap program model pertanian baru, ataupun tindakan terhadap masalah-masalah pertanian yang dihadapi selama oleh masyarakat.

\section{DAFTAR PUSTAKA}

Budhirianto, Syarif. 2015. Pola komunikasi untuk permberdayaan kelompok informasi masyarakat dalam menyukseskan program swasembada pangan. Jurnal Pakommas, Vol. 18. No. 2. Agustus 2015: 127-138

Effendy, Onong Uchjana. 2005. Ilmu Komunikasi Teori dan Praktek. PT Remaja Rosdakarya : Bandung

Firmansya, Hairi. Yulianti, Mira. Alif, Muhammad. 2017. Strategi komunikasi dalampenguatankapasitaskelembagaan pada pengelolaan lahan gambut melalui peningkatan sumberdaya manusia di sektor pertanian Kalimantan Selatan. MetaCommunication; Journal of communication studies. P ISSN :23564490, E ISSN: 2549-693X Vol II No 1 Maret 2017

Kholisoh, Nur dan Primayanti. 2016. Model Komunikasi kelompok tentang makna pernikahan antar generasi dikalangan kelas menengah jakarta. Jurnal ASPIKOM. Volume 3, Nomor 1, Juli 2016 
Kusumadinata, Ali Alamsyah dan Fitrah, Maria. 2017. Strategi komunikasi pelayanan publik melalui progrram pos pemberdayaan keluarga. Jurnal ASPIKOM. Volume 3, Nomor 2, Januari 2017

Nurudin. 2017. Ilmu Komunikasi Ilmiah dan Populer. Rajawali Pers. Jakarta

Richard, T. 2009. Qualitative versus quantitative Methods, Understanding qualitative methods are superior for criminology and criminal justice. Journal of Theoritical and philosophical criminology. University of louisville
Rangkuti, Parlaungan Adil. 2009. Strategi komunikasi membangun kemandirian pangan. Jurnal Litbang Pertanian, 28 (2), 2009.

Rogers, Everett M. 1995. Diffusion of innovations. Fourth Edition. Free Press. NewYork

Sadono, Dwi. 2009. Perkembangan pola komunikasi dalam pertanian penyuluhan pertanian di Indonesia. Jurnal Komunikasi Pembangunan. ISSN 1693-3699. Vol. 07, No. 2 
120 | Komunikasi, Vol. XIII No. 02, September 2019: 109-120 